\title{
Study on the Tax Management Path of Colleges from the Perspective of Internal Control
}

\author{
Zhijuan Lin \\ Yunnan Jiaotong College, Kunming, Yunnan, 650000
}

Keywords: Tax Management Path, Internal Control, College Management

\begin{abstract}
Tax administration in colleges is an important economic management activity, which is closely related to the economic benefits of colleges. However, there are many taxes involved in taxation in colleges. There are always some problems in actual tax management. It is urgent to improve the tax management system, strengthen tax control, and prevent tax risks. This paper analyzes the problems existing in the tax administration of colleges from the perspective of internal control, and then puts forward some suggestions for operability.
\end{abstract}

\section{Introduction}

With the advancement of tax reform, college tax management has become an important part of university management. However, at present, the tax management awareness of Colleges is still relatively weak, the risk prevention and control ability is insufficient, the understanding of the tax system is not thorough, and tax management work cannot be carried out according to the requirements of tax reform, which hinders the development of Colleges to some extent. There are many types of taxes involved in taxation in Colleges. To reduce tax risks, universities must strengthen internal control and improve internal control mechanisms.

\section{Contents involved in university tax administration}

The taxation management of Colleges is the management, research, planning and processing of related businesses related to taxation in Colleges. At this stage, college taxation involves personal income tax, corporate income tax, and value-added tax.

In terms of personal income tax, according to the "Notice on Further Strengthening the Administration of Collection of Individual Income Taxes for High-income Persons" issued by the State Administration of Taxation and the "Administrative Measures for Individual Income Taxes" [1-2], higher income industries such as universities and electric power shall be included. Individual high-income university teachers are an important target of tax collection and management, and they also clearly stipulate the tax deduction standards and taxation methods for special year-end one-time bonuses.

Corporate income tax, according to the "Interim Regulations on Enterprise Income Tax", corporate income tax payers include, in addition to various types of enterprises, other organizations that have income from production and other income. For Colleges, there is no clear management method for the collection of corporate income tax. Most of them are based on the notice of the competent tax authorities, and they are only applied for the application of the enterprise model. There is no management method that combines the actual situation of the university.

VAT, with the implementation of the reform and tax increase system, the taxpayer pays the value-added tax, not the business tax. This change in taxation has also brought about certain changes in the taxation management of Colleges. The traditional tax planning model is no longer suitable for the needs of taxation work in Colleges. How to make rational use of existing preferential policies will become an important task for university management of value-added tax. [3]. 


\section{Problems in the tax administration of Colleges from the perspective of internal control}

Tax management is a systematic and professional job, and there are many issues to be aware of. At present, there are many problems in the taxation management of Colleges. Colleges are in a passive position in tax administration. They cannot strictly carry out tax management in accordance with China's tax laws, and weaken the tax management functions to a certain extent.

As the size of Colleges expands, economic activities involving taxation are also increasing. However, at present, Colleges have not yet formed a correct tax management awareness, did not recognize the importance of tax administration, and did not set up a special tax administration department to be responsible for taxation. Paying taxes according to law is an obligation that every citizen should fulfill. However, due to the lack of correct tax management awareness in Colleges, his attention to relevant tax-related information is not high, which leads to the lack of tax laws and tax knowledge, and some tax evasion. The phenomenon of water leakage.

With the advancement of China's tax reform, the content of tax work has also undergone certain changes, and this change has placed higher demands on financial personnel. However, as far as the current situation is concerned, the financial staff of Colleges are still carrying out tax-related work in accordance with past work experience. The ability in tax-related business is slightly insufficient, and tax management cannot be effectively carried out in accordance with the requirements of China's tax reform. Seriously affected the economic benefits of Colleges. In addition, tax work is a complicated task, involving a lot of content, and financial personnel in the actual work is difficult to be comprehensive, standardized, and even many financial personnel under the administrative orders of college leaders, deliberately make false accounts, appear Some violations.

Tax management belongs to the category of economic management. In tax management, tax risk is an inevitable problem. The important reason for tax risk is the lack of tax management mechanism and the failure to effectively control and supervise tax management. At present, Colleges have not set up tax management positions, and their management functions are scattered. They have not yet formed a mechanism to match tax management work, which has seriously affected the institutionalization, legalization and standardization of universities. In addition, most college taxation work is carried out by the finance department. Since the university has not established an effective linkage mechanism with the tax authorities, when the tax authorities issue relevant tax self-examination matters, the university may fall into passiveness and even bear the burden. Big tax penalty risk.

Under the current social situation, information management has become an inevitable trend, and the realization of information management is conducive to improving work efficiency. At this stage, although the national taxation information construction has achieved remarkable results, many Colleges have not paid enough attention to the internal tax information construction, ignoring the importance of informationization in the daily operation of Colleges. On the one hand, Colleges believe that there is no need to invest the corresponding costs to promote the construction of tax information; on the other hand, the various departments of the university have not been closely linked, and the phenomenon of their own existence still exists. Due to the lack of information exchange platform within the university, the university The tax-related information was not shared, which affected the development of tax administration to a certain extent.

\section{The tax management path of Colleges from the perspective of internal control}

Tax administration in Colleges is an important task. Doing a good job in tax administration in Colleges is conducive to regulating the taxation behavior of Colleges, avoiding the development of tax evasion and taxation, and effectively reducing the tax burden of Colleges. However, there are many contents involved in taxation work in Colleges. In order to improve the level of tax management and reduce tax risks, effective measures must be taken to comprehensively supervise taxation work.

Tax management is closely related to the development of Colleges. As far as Colleges are concerned, there are many tax-related projects. It is the duty of Colleges and faculty and staff to pay 
taxes according to law. If Colleges do not pay attention to taxation management, they will be prone to tax evasion and taxation, and even increase the tax burden. In this regard, Colleges must correctly understand tax management work [4]. In accordance with the needs of taxation work, Colleges should set up special tax management positions to carry out targeted management of various tax-related matters, so as to ensure the efficient completion of various tax-related businesses. At the same time, university leaders should take the initiative to study tax laws, understand China's tax system reform, and carry out tax management work in combination with the characteristics of tax reform.

Paying taxes according to law is an important part of building a society ruled by law. For Colleges, their tax management work should be based on tax law and protected and regulated by law. In this regard, Colleges should pay attention to tax management work and establish a correct tax awareness. On the one hand, Colleges should make full use of various means to publicize tax law knowledge, so that faculty and staff can understand the country's various tax laws and policies, and at the same time, the tax authorities can more clearly understand the actual situation of Colleges; on the other hand, universities must be from the tax authorities. Employ relevant staff to the school to explain the tax law, and then raise the tax law awareness of college staff and staff [5].

With the complexity and diversification of the economic business of Colleges, the content of financial work in Colleges has become more diverse and complex. To improve the quality of taxation work, Colleges must pay attention to the training of financial personnel and actively create a high-quality, comprehensive A strong financial workforce. First, strengthen the training of existing financial personnel's abilities, comprehensively improve the knowledge reserve and business skills of financial personnel, especially the financial practice ability of financial personnel; secondly, strengthen the financial personnel's study of tax laws and tax systems, familiarize them with tax laws. Taxation-related content can carry out taxation work in accordance with tax laws and taxation requirements. At the same time, encourage and advocate financial personnel to enter the tax authorities to learn the latest tax law. In addition, Colleges should pay attention to the training of financial personnel's professional quality, comprehensively improve the professional quality and quality of financial personnel, so that financial personnel can actively participate in tax management work [6]. In addition, Colleges should hire professionals from the tax authorities to conduct technical training for financial personnel, introduce professional talents to the outside, and provide support for tax management.

The system is the guarantee for the smooth development of tax administration. Only a sound tax management system can promote the orderly development of taxation, reduce tax risks and improve the level of tax management. First of all, according to the principle of separation of incompatible posts mentioned in the Internal Accounting Control Code issued by the Ministry of Finance, Colleges should establish an internal control management mechanism that matches the taxation management work, improve the risk management mechanism, and clarify the taxation workflow. Clearly define the division of labor in each link, and do everything in one way, one tube and one knot. Secondly, improve the supervision mechanism and supervise the whole process of taxation, so as to effectively prevent the occurrence of power, illegality and chaos; in addition, the implementation of responsibility System, the responsibility of tax management work is put in place, so as to better regulate the behavior of staff and improve their sense of responsibility [7]. In addition, Colleges should formulate corresponding inspection systems, conduct repeated verifications of taxation work, and summarize and analyze various situations in tax management to provide reference for decision makers.

There are many tax-related projects in Colleges, and the realization of taxation management information can effectively link all departments of Colleges, thereby realizing the sharing of tax information and improving the level and efficiency of tax management. In this regard, Colleges should recognize the importance of taxation management information construction. First of all, it is necessary to increase investment, establish a tax information exchange platform within the university, and integrate all departments into the information system, so that the staff can collect the required data and efficiently complete various tax matters. Secondly, it is necessary to hire a 
software development company with $R \& D$ experience and develop relevant tax processing systems to support the relevant tax treatment of Colleges, so that the handling of relevant tax matters is more convenient and fast [8]. It is worth noting that in the process of promoting the construction of tax management information, universities should pay attention to the safety management of tax information, and increase the application of information security technology in tax information systems, such as encryption technology and identity authentication technology, and thus protect the tax system. Security, to avoid taxation information being tampered with and stolen.

First of all, combined with the requirements of the tax reform, actively change the accounting method to ensure that Colleges can carry out tax management; secondly, we must strengthen tax management, and then implement tax management work in every aspect of the university, regularly carry out tax settlement, strengthen assessment, plus The implementation of the large tax law, in strict accordance with tax law requirements for tax management [9].

The taxation agency is the functional department that organizes the income according to the tax law and exercises the state's taxation rights. It is the organizational guarantee for the correct implementation of the state taxation policy and the realization of the taxation function. When the national tax system and tax law change, the main body that grasps this change in the first time is the taxation institution. The cooperation between the university and the taxation institution can understand the latest contents of the tax law and the tax system, and facilitate the university to carry out tax management work. Reduce tax risks [10]. In this regard, Colleges should maintain close contact with the local tax authorities, arrange special personnel to be responsible for the docking work with the tax authorities, thereby reducing the phenomenon of tax information asymmetry and promoting the efficient development of tax administration in Colleges.

\section{Conclusion}

In summary, with the continuous expansion of the scale of Colleges, the complexity and diversification of economic business, it is particularly important to strengthen the taxation management of Colleges. However, at present, there are weak tax management awareness and insufficient financial personnel in the tax administration of Colleges. The lack of tax management system and the low level of tax information management have seriously hindered the efficient development of tax administration. Based on the perspective of internal control, Colleges should speed up the improvement of tax management mechanisms, increase the training of financial personnel, actively promote the construction of taxation management information, increase the promotion and learning of tax laws, and maintain close contact with tax authorities. In addition, it provides effective conditions for tax administration and promotes the effective implementation of tax administration.

\section{References}

[1] Sun Ying, Qi Ling. Preliminary Study on Tax Risk Control in Colleges Based on Auditing__ Taking Kunming University of Science and Technology as an Example[J].Research of Tax Economics, 2018, 23(02): 56-59.

[2] Qiu Shan. Analysis of the problems and countermeasures of internal tax management in Colleges [J]. Taxation, 2018 (07): 16.

[3] Fu Shuyuan. Construction and Evaluation of University Tax Risk Management System_—From the Perspective of Internal Control [J]. Commercial Accounting, 2017(21):85-87.

[4] Huang Ming. On Tax Risks and Solutions in Colleges [J]. Finance and Economics (Academic Edition), 2017(20): 120-121.

[5] Ru Ruyuan. The problems of taxation in Colleges and the countermeasures of risk management [J]. Taxation, 2017 (25): 17.

[6] Zheng Meijuan. Taxation Risk Control in Colleges from the Perspective of Auditing [J]. 
Taxation, 2017(14): 17.

[7] Yang Yuanfeng. Research on the development and practice of internal tax management in Colleges [J]. China Management Information, 2016, 19 (20): 24.

[8] Cao Shifeng. The Impact of Comprehensive Camp Reform on University Taxation Work [J]. China Business Theory, 2016(22): 178-179.

[9] Sukla. Analysis of the Perfect Path of University Tax Administration[J]. China Collective Economy, 2015(21): 81-82.

[10] Xiao Nahui. Problems and Countermeasures in Internal Tax Management of Colleges [J]. Administrative Assets and Finance, 2014(21): 49-50. 